\title{
Design and construction of enzyme-nanozyme integrated catalyst as a multifunctional detection platform
}

Junyang Xu, ${ }^{\text {a }}$ Huajiao Liu, a Jianqiao Liu, a Ying He, a Jing Gao, a Jiafu Shi, ${ }^{\text {b }}$ Yanjun Jiang*a, c

a School of Chemical Engineering and Technology, Hebei University of Technology, Tianjin, 300130, P. R. China

b Tianjin Key Lab of Biomass/Wastes Utilization, School of Environmental Science \& Engineering, Tianjin University, Tianjin, 300072, P. R. China

c National-Local Joint Engineering Laboratory for Energy Conservation of Chemical Process Integration and Resources Utilization, Hebei University of Technology, Tianjin 300130, P. R. China

Corresponding Author

*E-mail: yanjunjiang@hebut.edu.cn; 


\section{S1. Chemicals}

Ferric chloride $\left(\mathrm{FeCl}_{3}\right)$, glucose, sodium citrate, hydrogen peroxide $\left(\mathrm{H}_{2} \mathrm{O}_{2}\right)$, disodium hydrogen phosphate $\left(\mathrm{Na}_{2} \mathrm{HPO}_{4}\right)$, sodium hydrogen phosphate $\left(\mathrm{NaH}_{2} \mathrm{PO}_{4}\right)$, ethylene glycol, sodium acetate anhydrous $\left(\mathrm{CH}_{3} \mathrm{COONa}\right)$, 4-aminoantipyrine (4-AAP) and 2,4-dichlorophenol (2,4-DP) were purchased from Tianjin Keruisi Fine Chemical Co. Ltd. (Tianjin, China). Copper chloride dihydrate, guanosine 5'-monophosphate (GMP) disodium salt, $\beta$-arbutin, 2-morpholinoethanesulfonic acid (MES), 2-[4-(2hydroxyethyl)piperazin-1-yl]ethanesulfonic acid (HEPES) and laccase were purchased from Shanghai Aladdin Bio-Chem Technology Co., Ltd. (Shanghai, China). Horseradish peroxidase (HRP), GOx (from Aspergillus niger) and laccase (from Trametes versicolor) were purchased from Sigma-Aldrich Trading Co. Ltd., (Shanghai, China) and Shanghai Yuanye Bio-Technology Co., Ltd., respectively.

\section{S2. Methods}

\section{S2.1. Effects of $\mathrm{pH}$ and temperature on the catalytic activity}

For $\mathrm{Fe}_{3} \mathrm{O}_{4} @ \mathrm{Cu} / \mathrm{GMP}$ or laccase, the influence of $\mathrm{pH}$ on their activity was determined by the following method. Solution A was prepared with buffers at different $\mathrm{pH}$ values. $1.5 \mathrm{~mL}$ of Solution A and $1.4 \mathrm{~mL}$ of buffer with a corresponding $\mathrm{pH}$ was incubated at $25^{\circ} \mathrm{C}$ for 10 minutes, and then $0.1 \mathrm{~mL}$ catalyst $(100 \mathrm{mg} / \mathrm{mL})$ was added to react for $30 \mathrm{~min}$. The absorbance of red solution at $500 \mathrm{~nm}$ was determined. For $\mathrm{Fe}_{3} \mathrm{O}_{4} @ \mathrm{Cu} / \mathrm{GMP}-\mathrm{GOx}$ or free GOx\&HRP, the influence of $\mathrm{pH}$ on its activity was determined in the system of $1.5 \mathrm{~mL}$ Solution A, $1.3 \mathrm{~mL}$ buffers solution with a corresponding $\mathrm{pH}, 0.1 \mathrm{~mL}$ glucose and $0.1 \mathrm{~mL}$ catalyst $(100 \mathrm{mg} / \mathrm{mL})$.

The effect of temperature on catalyst activity was determined by the following method. For $\mathrm{Fe}_{3} \mathrm{O}_{4} @ \mathrm{Cu} / \mathrm{GMP}, 1.5 \mathrm{~mL}$ Solution A, $1.4 \mathrm{~mL}$ MES buffer and $0.1 \mathrm{~mL}$ catalyst reacted at different temperatures for $30 \mathrm{~min}$. The absorbance of reaction system was determined after removing the catalyst. For $\mathrm{Fe}_{3} \mathrm{O}_{4} @ \mathrm{Cu} / \mathrm{GMP}-\mathrm{GOx}$ or free GOx\&HRP, the effect of temperature on its activity was determined in the system of $1.5 \mathrm{~mL}$ solution A (MES buffer,30 mM, pH 5.5), $1.3 \mathrm{~mL}$ MES buffer, $0.1 \mathrm{~mL}$ glucose solution and $0.1 \mathrm{~mL}$ catalyst $(100 \mathrm{mg} / \mathrm{mL})$.

\section{S2.2. Stability test of $\mathrm{Fe}_{3} \mathrm{O}_{4} @ \mathrm{Cu} / \mathrm{GMP}-\mathrm{GOx}$}

Free GOx\&HRP, laccase, $\mathrm{Fe}_{3} \mathrm{O}_{4} @ \mathrm{Cu} / \mathrm{GMP}$ and $\mathrm{Fe}_{3} \mathrm{O}_{4} @ \mathrm{Cu} / \mathrm{GMP}-\mathrm{GOx}$ were used as parallel control to study the thermal, mechanical and storage stability. To determine 
their thermal stability, the four catalysts were incubated in $55^{\circ} \mathrm{C}$ water baths for different time, and then immersed to ice bath for cooling to determine their catalytic activity. To measure the mechanical stability, the catalysts were incubated for different time at $25{ }^{\circ} \mathrm{C}$ with $1600 \mathrm{r} / \mathrm{min}$ stirring, and their catalytic activity was measured under mild magnetic stirring. The catalysts were soaked in HEPES buffer $(10 \mathrm{mM}, \mathrm{pH} 6.8)$ respectively and stored at room temperature. The storage stability was investigated by measuring the residual activity with the change of storage time.

The reusability of $\mathrm{Fe}_{3} \mathrm{O}_{4} @ \mathrm{Cu} / \mathrm{GMP}$ was determined as follows. $1.5 \mathrm{~mL}$ Solution A, $1.4 \mathrm{~mL}$ MES buffer and $0.1 \mathrm{~mL} \mathrm{Fe}_{3} \mathrm{O}_{4} @ \mathrm{Cu} / \mathrm{GMP}(100 \mathrm{mg} / \mathrm{mL})$ were incubated at $25{ }^{\circ} \mathrm{C}$ for $30 \mathrm{~min}$. After separating the catalyst from the reaction solution, the supernatant was used to determine the activity and the solid catalyst was washed with fresh buffers. Then Solution A and MES buffers were re-add to $\mathrm{Fe}_{3} \mathrm{O}_{4} @ \mathrm{Cu} / \mathrm{GMP}$ for the next cycle. Similarly, the catalytic activity of $\mathrm{Fe}_{3} \mathrm{O}_{4} @ \mathrm{Cu} / \mathrm{GMP}-\mathrm{GOx}$ in different batches was determined using $1.5 \mathrm{~mL}$ Solution A, $1.3 \mathrm{~mL}$ MES buffers, and $0.1 \mathrm{~mL}$ glucose solution as the reaction system. 


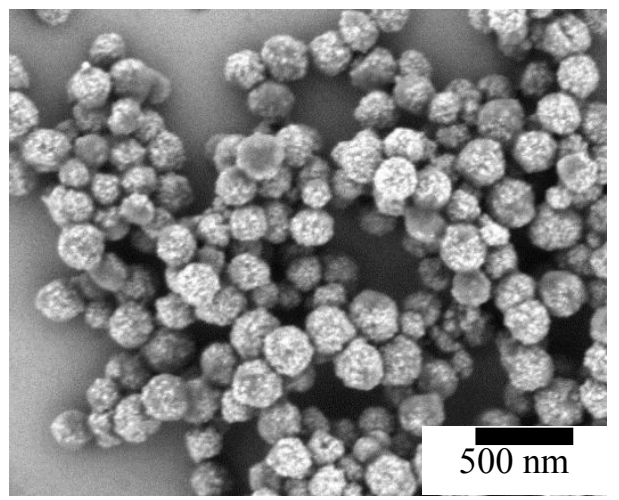

Figure S1. SEM image of $\mathrm{Fe}_{3} \mathrm{O}_{4}$. 


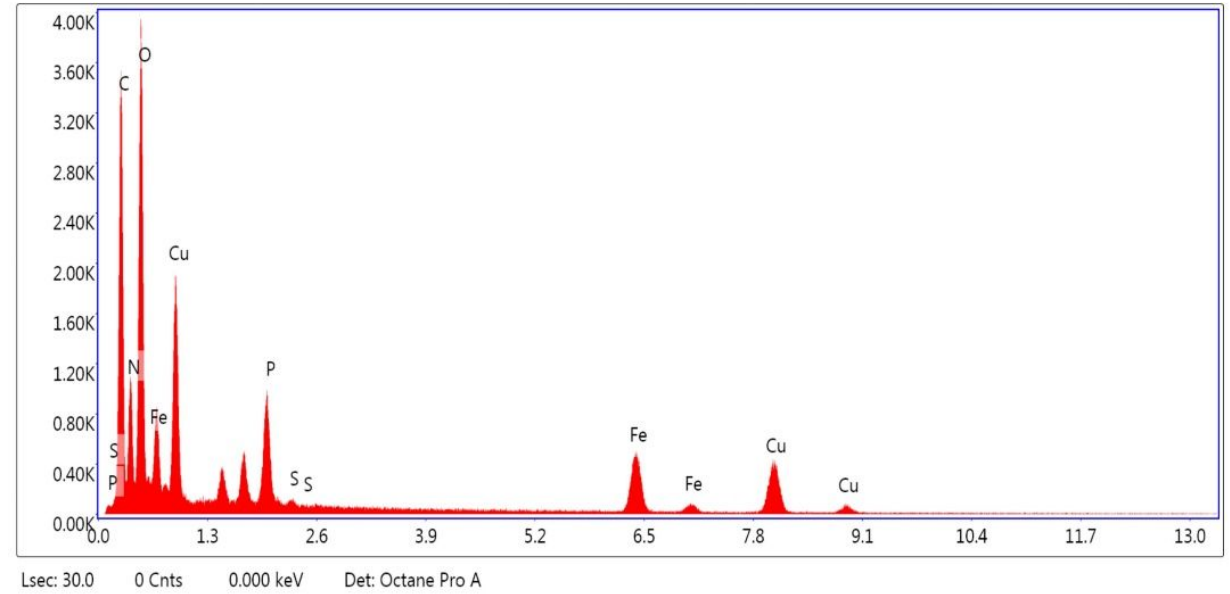

Figure S2. EDX elemental mappings of $\mathrm{Fe}_{3} \mathrm{O}_{4} @ \mathrm{Cu} / \mathrm{GMP}-\mathrm{GOx}$. 


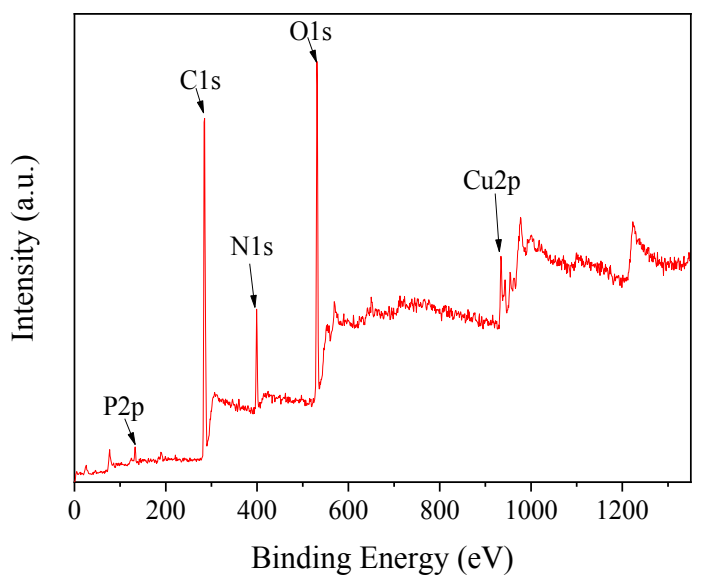

Figure S3. XPS spectra of $\mathrm{Fe}_{3} \mathrm{O}_{4} @ \mathrm{Cu} / \mathrm{GMP}-\mathrm{GOx}$ 


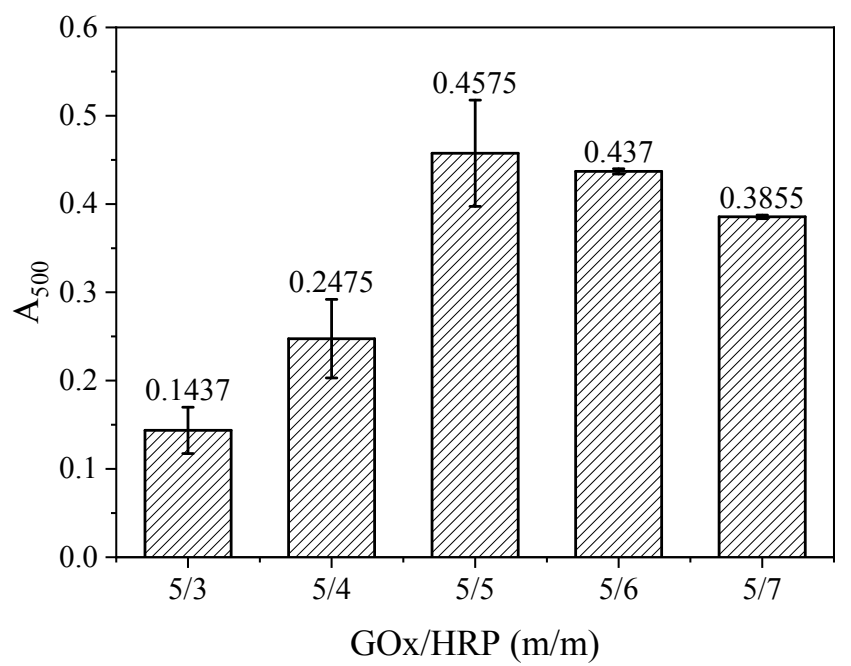

Figure S4. The activity of free GOx\&HRP at different mass ratios (GOx/HRP=5/3, 5/4, 5/5, 5/6, $5 / 7)$. 


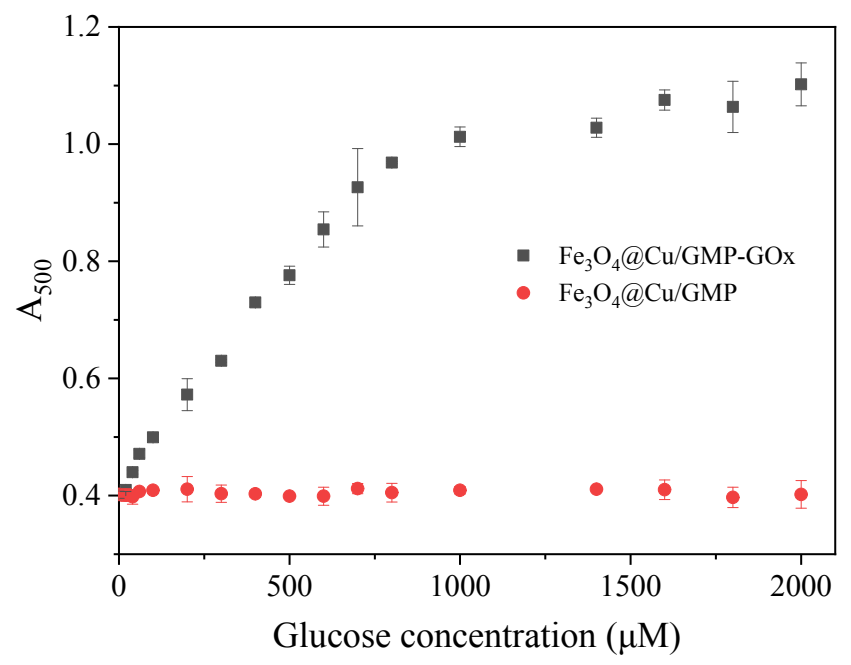

Figure S5. Comparison of $\mathrm{Fe}_{3} \mathrm{O}_{4} @ \mathrm{Cu} / \mathrm{GMP}$ and $\mathrm{Fe}_{3} \mathrm{O}_{4} @ \mathrm{Cu} / \mathrm{GMP}-\mathrm{GOx}$ in the detection of glucose. 


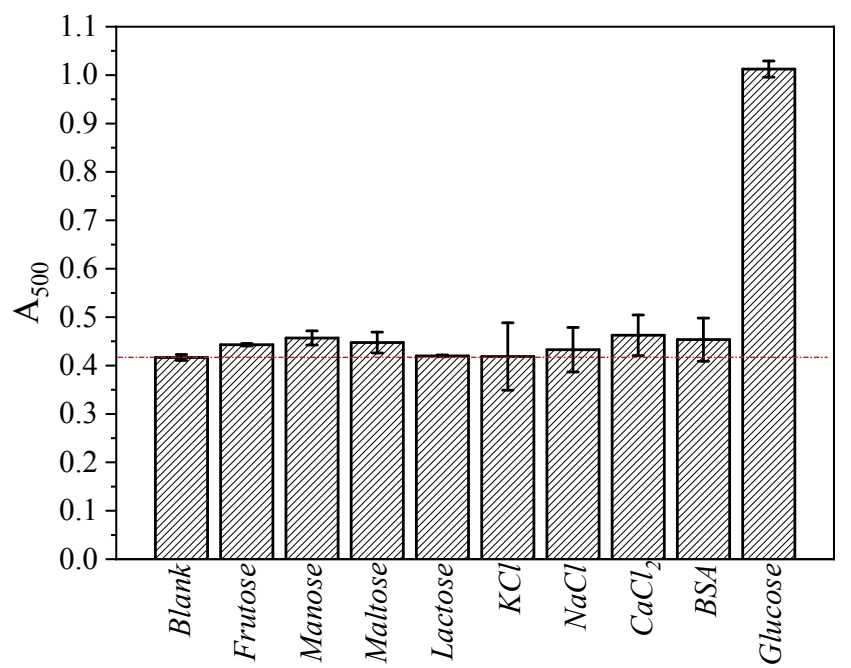

Figure S6. The selectivity and anti-interference performance of $\mathrm{Fe}_{3} \mathrm{O}_{4} @ \mathrm{Cu} / \mathrm{GMP}-\mathrm{GOx}$ for 500 $\mu \mathrm{M}$ glucose in comparison to $5000 \mu \mathrm{M} \mathrm{NaCl}, \mathrm{KCl}, \mathrm{CaCl}_{2}$, fructose, mannose, maltose, lactose, and $1 \mathrm{mg} / \mathrm{mL}$ BSA. 

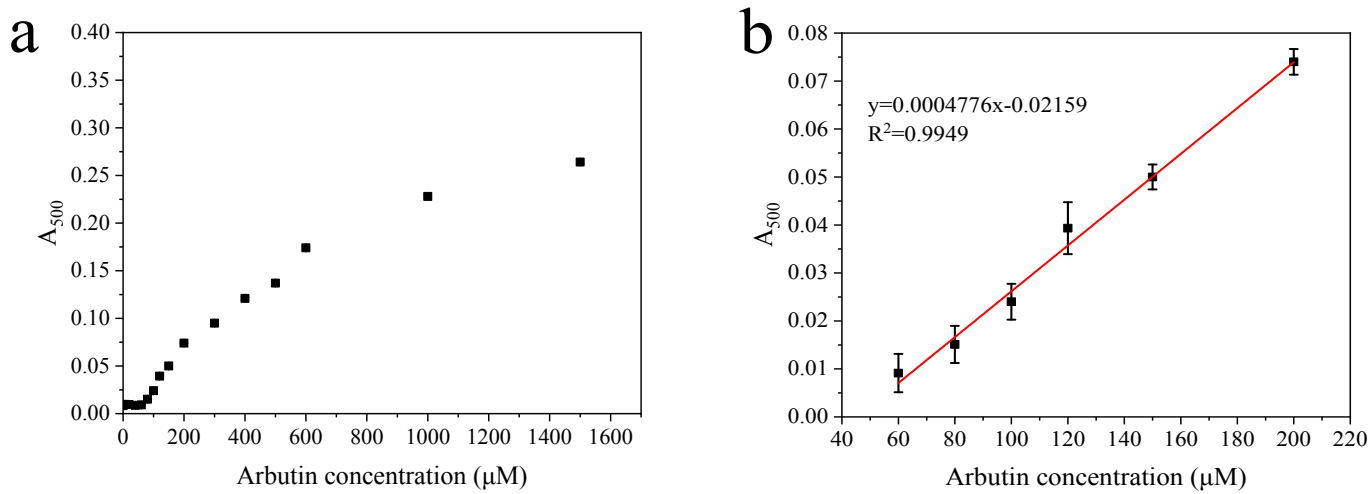

Figure S7. (a) The absorption of 4-AAP solution containing $\mathrm{Fe}_{3} \mathrm{O}_{4} @ \mathrm{Cu} / \mathrm{GMP}, 16.7 \mathrm{mM}$ glucose and different concentrations of arbutin; (b) the corresponding linear calibration plots. 
Table S1 Quantification of $\mathrm{H}_{2} \mathrm{O}_{2}$ in tap water using $\mathrm{Fe}_{3} \mathrm{O}_{4} @ \mathrm{Cu} / \mathrm{GMP}$

\begin{tabular}{cccc}
\hline $\mathrm{H}_{2} \mathrm{O}_{2}$ added $(\mathrm{mM})$ & $\mathrm{H}_{2} \mathrm{O}_{2}$ recovered (mM) & $\begin{array}{c}\text { Relative standard } \\
\text { deviation (RSD) (\%) }\end{array}$ & Recovery (\%) \\
\hline 0.495 & 0.503 & 4.375 & 101.6 \\
0.991 & 0.962 & 2.784 & 97.1 \\
1.982 & 1.916 & 3.076 & 96.7 \\
2.972 & 3.114 & 0.858 & 104.8 \\
3.963 & 4.075 & 4.310 & 102.8 \\
4.954 & 4.950 & 2.451 & 99.9 \\
5.945 & 6.035 & 4.945 & 101.5 \\
\hline
\end{tabular}


Table S2 Quantification of glucose in serum using $\mathrm{Fe}_{3} \mathrm{O}_{4} @ \mathrm{Cu} / \mathrm{GMP}-\mathrm{GOx}$

\begin{tabular}{ccccccc}
\hline $\begin{array}{c}\text { Hexokinase } \\
\text { method } \\
(\mathrm{mM})\end{array}$ & Diluted & $\begin{array}{c}\text { Glucose } \\
\text { added } \\
(\mathrm{mM})\end{array}$ & $\begin{array}{c}\text { Final } \\
\text { concentration } \\
(\mathrm{mM})\end{array}$ & $\begin{array}{c}\text { Glucose } \\
\text { recovered } \\
(\mathrm{mM})\end{array}$ & $\begin{array}{c}\text { Relative } \\
\text { standard } \\
\text { deviation } \\
(\mathrm{RSD})(\%)\end{array}$ & $\begin{array}{c}\text { Recovery } \\
(\%)\end{array}$ \\
\hline 5.58 & $5 / 9$ & $/$ & 3.100 & 3.119 & 1.134 & 99.2 \\
5.58 & $2 / 3$ & $/$ & 3.720 & 3.547 & 4.598 & 99.9 \\
5.58 & $5 / 6$ & $/$ & 4.650 & 4.444 & 3.326 & 98.3 \\
5.58 & $/$ & $/$ & 5.580 & 5.597 & 2.998 & 102.9 \\
5.58 & $/$ & 0.558 & 6.138 & 5.854 & 3.706 & 99.8 \\
5.58 & $/$ & 1.116 & 6.696 & 6.666 & 1.924 & 97.6 \\
5.58 & $/$ & 2.97 & 8.38 & 7.905 & 3.186 & 98.2 \\
\hline
\end{tabular}


Table S3 Quantification of arbutin in moisturizing cream using $\mathrm{Fe}_{3} \mathrm{O}_{4} @ \mathrm{Cu} / \mathrm{GMP}-\mathrm{GOx}$

\begin{tabular}{cccc}
\hline$\beta$-arbutin added (mM) & $\begin{array}{c}\beta \text {-arbutin recovered } \\
(\mathrm{mM})\end{array}$ & $\begin{array}{c}\text { Relative standard } \\
\text { deviation (RSD) (\%) }\end{array}$ & Recovery (\%) \\
\hline 3 & 2.979 & 1.453 & 99.3 \\
4.5 & 4.553 & 4.745 & 101.2 \\
6 & 6.270 & 2.072 & 104.5 \\
7.5 & 7.497 & 4.457 & 100 \\
9 & 9.114 & 4.546 & 101.3 \\
10.5 & 10.500 & 3.111 & 100 \\
12 & 11.97 & 1.230 & 99.8 \\
\hline
\end{tabular}

